\title{
POST-WAR CINEMA AND MODERNITY
}

\author{
A FILM READER
}

Edited by

John Orr and Olga Taxidou 
(C) Introductions, selection and editorial material, John Orr and Olga Taxidou, 2000

Transferred to digital print 2007

Edinburgh University Press Ltd 22 George Square, Edinburgh

Typeset in Sabon and Gill Sans by Bibliocraft Ltd, Dundee, and printed and bound in Great Britain by CPI Antony Rowe, Eastbourne

A CIP record for this book is available from the British Library

ISBN 0748612823 (hardback) ISBN 0748612815 (paperback)

The right of the contributors to be identified as authors of this work has been asserted in accordance with the Copyright, Designs and Patents Act 1988. 